\title{
Variations in the Chemical Composition of the Essential Oil of Lavandula angustifolia Mill., Moldoveanca 4 Romanian Variety
}

\author{
MIHAELA BOGDAN ${ }^{1}$, SIMONA BUNGAU ${ }^{1 *}$, DELIA MIRELA TIT ${ }^{1 *}$, LUCIAN COPOLOVICI ${ }^{2}$, \\ TAPAN BEHL ${ }^{3}$, PAVEL OTRISAL ${ }^{4}$, LOTFI ALEYA ${ }^{5}$, GABRIELA CIOCA ${ }^{6}$, DOINA BERESCU ${ }^{7}$, \\ DIANA UIVAROSAN ${ }^{1}$, DANA MARIA COPOLOVICI ${ }^{2}$ \\ ${ }^{1}$ University of Oradea, Faculty of Medicine and Pharmacy, 29 N. Jiga Str., 410028, Oradea, Romania \\ ${ }^{2}$ Aurel Vlaicu University, Faculty of Food Engineering, Tourism and Environmental Protection, Institute for Research, \\ Development and Innovation in Technical and Natural Sciences, 2 Elena Dragoi Str., 310330, Arad, Romania \\ ${ }^{3}$ Chitkara College of Pharmacy, Chitkara University, 140401 Punjab, India \\ ${ }^{4}$ Faculty of the Physical Culture, Palacky University Olomouc, 77111 Olomouc, Czech Republic \\ ${ }^{5}$ Laboratoire Chrono-environnement, Universite de Franche-Comte, 25000 Besancon, France \\ ${ }^{6}$ Lucian Blaga University of Sibiu, Faculty of Medicine, 10 Victoriei Blvd., 550024 Sibiu, Romania \\ ${ }^{7}$ SC Ecoland Production SRL, 11 Revolutiei Sq. 11, 710237, Botosani, Romania
}

\begin{abstract}
In this research, the variations in the chemical composition of the Lavandula angustifolia Mill. essential oil, the Romanian variety Moldoveanca 4, obtained from the same culture, in the same harvesting and extraction conditions, during the years 2016-2018, representing the years 2-4 of culture. Lavandula angustifolia Mill. flowers were supplied from an ecological-crops from $N-E$ Romania and the essential oils were obtained by hydro distillation of freshly harvested flowers. To determine the chemical composition, the essential oil was semi-quantitatively analysed by using gas chromatography coupled with mass spectrometry (GC-MS). In all the samples, 30 organic compounds were identified, linalool and linalyl acetate being in similar concentrations (23.51-27.39\% for linalool and 26.60-40.66\% for linalyl acetate). Changes in chemical composition were observed in 2017 and 2018. Also, in 2017 was determined an increase in the quantity of linalyl acetate (from 26.60 to $40.66 \%)$, and a slight decrease in linalool content; in 2018, the concentration in linalyl acetate remained approximately the same as in 2017 (38.03 versus $40.66 \%$ ) and there was an increase in linalool compared to the previous years $(27.39 \%$, compared to $23.51 \%$ in 2017 and $26.22 \%$ in 2016). The chemical composition of the essential oils obtained from flowers of Lavandula angustifolia L., Moldoveanca 4 variety, showed substantial changes of the chemical profile describing the compounds during the analysed three years, as was determined by GC-MS analyses.
\end{abstract}

Keywords: Lavandula angustifolia oil, hydro distillation, gas-chromatography, mass spectrometry

\section{Introduction}

Lavandula angustifolia (true lavender) is the lavender species most commonly cultivated, especially in the south-eastern part of Europe, having therapeutic importance due to the plant product obtained, respectively to the inflorescences (fresh or dried lavender flowers) - Lavandulae flos. The flowers, in pharmaceutical use, are appreciated especially for the essential oil - Lavandulae aetheroleum, the active principle of the product that is increasingly used [1,2].

Essential oils of Lavandula species are volatile and aromatic substances composed of mixtures of secondary metabolites synthesized by plants, which mainly include two groups of related biosynthetic compounds, such as $\mathrm{C} 10-\mathrm{C} 15$ terpene derivatives of isoprene, aromatic terpenoids and aliphatic small molecular weight compounds. The characteristic lavender flavour of the essential oil is attributed to low molecular weight monoterpenes $\left(\mathrm{C}_{10} \mathrm{H}_{16}\right)[1,3]$. 
The major components in L. angustifolia essential oil are linalool (20-45\%) and linalyl acetate (2547\%) (Figure 1), with moderate concentrations of lavandulil acetate, terpinen-4-ol, lavandulol, followed by 1,8-cineol (eugenol) and camphor present in small amounts. Lavandulol, lavandulil acetate, cis- and trans-occene are characteristic compounds of lavender oil. Other chemical compounds present in lavender essential oil are: $\beta$-cariophenylene, $\alpha$-pinene, limonene, $\alpha$-terpineol, nerol, geraniol, borneol, sabium, etc. [3]

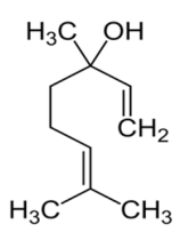

Linalool

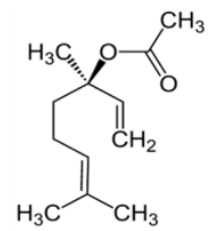

Linalyl acetate

Figure 1. Chemical structure of major

components of lavender essential oil

With a high concentration of linalool / linalyl acetate and camphor in low amounts, Lavandula angustifolia essential oil is considered to have the most beautiful perfume/fragrance and is the most demanded oil, used in the aromatherapy and cosmetics industry $[1,4,5]$. The number of components in the essential oil varies greatly, depending on the species, variety, altitude, weather conditions of the year, pedoclimatic conditions of the cultivation area, as well as separation technology (steam distillation, organic solvent extraction, supercritical fluid extraction with carbon dioxide, maceration, percolation, fractional distillation, etc.) [1]. The yield of distillation to produce essential oil varies with plant age: it reaches the maximum after 5-7 years and becomes very low after 10-12 years. The maximum content of ethereal oil is found to be at the beginning of blooming, between the 9 a.m. and 2 p.m. in that day. Early harvesting results in loss of essential oil yield, but also in its quality, because in this case in essential oil predominates linalool and the concentration of linalyl acetate does not exceed 8-10\%. Lavender harvesting is not recommended on rainy weather or on strong windy days, because glandular trichomes, where the essential oil is produced and secreted, that is are on leaves and flowers, are destroyed and the oil content decreases [1]. When drying, the flowers lose 35-47\% of the essential oil. That is why is recommended harvesting and processing fresh inflorescences, rather than harvesting, drying and afterwards distilling the essential oil.

The chemical composition of lavender oil is important because it differs from one species to another and influences the therapeutic effects. In the case of Lavandulae angustifoliae aetheroleum, aromatherapy requires a content of $40-50 \%$ esters (predominantly linalyl acetate), 30-40\% monoterpenols (especially linalool), 7-13\% monoterpene hydrocarbons (mainly ocimene), 8\% 1.5\% oxides (especially 1,8-cineol) [5,6]. The last edition of the European Pharmacopoeia and the Xth edition of Romanian Pharmacopoeia [7,8] provide for Lavandulae angustifolia essential oil a content of $20-45 \%$ linalool; $25-47 \%$ linalyl acetate; alpha-terpineol max. $2 \%$; lavandulic acetate min. $0.2 \%$; lavandulol min. $0.1 \%$; 1,8-cineol (eugenol) max. $2.5 \%$; camphor max. $1.2 \%$.

In therapy, the main uses of the essential oil of Lavandula angustifolia are based on the following pharmacological effects: sedative, anxiolytic [9], mood modulator [9,10], anticonvulsant and antidepressant [6,9], but also anti-inflammatory, anti-rheumatic, healing, skin regenerative, antiseptic, antibacterial [11], antifungal and even hypotensive [12]. The sedative action of the volatile oil is attributed to linalyl acetate and is mediated via the olfactory receptors pathway, but it is also possible directly at the central nervous system level $[13,14]$. Experimental studies carried out on animals (mice) have demonstrated the anxiolytic properties of lavender oil, this also increasing the length of sleep induced by pentobarbital [14].

In a recent work, it was demonstrated that the oral administration of true lavender essential oil decreased spared-nerve injury-induced neuropathic pain symptoms in a mice model. Lavender 
essential oil decreased the phosphorylation of several proteins from MAPK family: JNK1, ERK1, ERK2, and decreased the levels of inducible nitric oxide synthase (iNOS) in the spinal cord. The involvement of the endocannabinoid system was detected using in vitro inhibition of the FAAH and MALG enzymes and by in vivo experiments with CB1 antagonist. This treatment did not modify the behaviour, the memory function, locomotor activity or motor coordination of the mice [15]

Linalool, one of the major components of the lavender essential oil, develops central-inhibitory effects, acting as anticonvulsant and inhibiting spontaneous motor activity [16,17]. Administered in high doses, linalool acts by reducing motor coordination and prolongs the narcotic action of barbiturates, ethyl alcohol/ethanol and chloral hydrate [14,15]. In high doses it proved to be even narcotic, having similar action to gamma-aminobutyric acid (GABA), CNS inhibitor mediator [16-18].

Consequently, the therapeutic effects of lavender essential oil depend on its chemical composition, which in turn varies with a number of factors (plant age, harvest time, climate conditions, soil properties, extraction methods, pollution, etc.) [19-21]. Therefore, determining the chemical composition of the oil used in therapy or in the preparation of supplements is essential in determining their quality and effects [22-23].

The influence that the material (plastic, glass, metal) from which the storage container (of lavender oil or any natural extracts) is made has on the chemical composition of the content, has been demonstrated by numerous recent studies [4]. The industrial field dealing with this aspect abounds with increasingly optimized attempts to obtain as few active / reactive materials in relation to the content [24-27].

In this study, the variations of the chemical composition of the essential oil of Lavandula angustifolia Mill., Moldoveanca 4 (an early variety, patented in Romania) were determined. The plants from which the flowers analysed subsequently were collected were grown under the same growing conditions, harvested in the same way and subjected to analysis using the same extraction method. The period of study was between 2016-2018, representing years 2-4 of lavender culture.

\section{Materials and methods}

\subsection{Plant Material}

Lavandula angustifolia Mill. (Moldoveanca 4) flowers were obtained from an organic crop located in a farm, Botosani County, Romania $\left(47^{\circ} 41^{\prime} 51^{\prime \prime} \mathrm{N} 26^{\circ} 38^{\prime} 53^{\prime \prime} \mathrm{E}\right)$, being harvested in the summer of years 2016-2018. To obtain the essential oil, the flowers were harvested in the most favourable vegetation phase, when about $50 \%$ of the flowers are open. Each time, the harvesting was done manually, in the second half of June, in the first part of the sunny days, between 10-11.30 a.m.

\subsection{Method}

The essential oil was obtained by hydro distillation from the freshly harvested plant material. The distillation device used consists of a water treatment installation (distillation, demineralization), an electric steam generator, two containers of $500 \mathrm{~mL}$ each, for plant distillation, a vessel with coil for cooling the distilled product, a Florence flask to separate the distillate into essential oil and floral water.

The sterilized, softened water enters the steam production installation. The resulted steam is guided through a pipe into the dry vegetable product vat. The process takes about $1 \mathrm{~h}$ at a constant temperature of $100{ }^{\circ} \mathrm{C}$. The resulting vapours are condensed in the vessel with coils, a process that happens in cold environment, resulting in essential oil and floral water, respectively. The obtained essential oil, with a yield approx. 5-5.5\%, was dried by using anhydrous sodium sulphate (Merk, Germany) and packed in dark (amber) glass bottles for storage, then kept at a temperature of $4{ }^{\circ} \mathrm{C}$ till being used for GC-MS analyses. The parameters that characterise the obtained lavender essential oils are presented in Table 1. 
Table 1. Physical and chemical characteristics of lavender essential oils obtained through hydro distillation

\begin{tabular}{|c|c|c|c|c|c|}
\hline \multirow{2}{*}{ Parameter } & \multirow{2}{*}{ Unit of Measure } & \multicolumn{3}{|c|}{ Aspect/Value } & \multirow{2}{*}{$\frac{\text { Method }}{\text { Reference }}$} \\
\hline & & 2016 & 2017 & 2018 & \\
\hline Appearance & - & \multicolumn{3}{|c|}{ Clear liquid } & \multirow{4}{*}{ [7] } \\
\hline Colour & - & \multicolumn{3}{|c|}{ Pale yellow } & \\
\hline Acidity index & $\mathrm{mg} \mathrm{KOH} / \mathrm{g}$ & 1.00 & 1.50 & 1 & \\
\hline $\begin{array}{l}\text { Solubility in alcohol } \\
\text { (ethanol } 70^{c} \text { ) }\end{array}$ & $\mathrm{V} / \mathrm{V}$ & $1: 3$ & $1: 3$ & $1: 3$ & \\
\hline
\end{tabular}

\subsection{Characterization by GC-MS of lavender essential oils}

The chemical compositions of the essential oils have been determined using Gas-Chromatograph Agilent Technology 7820A (Agilent Scientific, USA) coupled with mass spectrometer MSD 5975 (Agilent Technology, USA). A capillary column DB 5: $(30 \mathrm{~m} \times 250 \mu \mathrm{m} \times 0.25 \mu \mathrm{m})$ (Agilent Technology, USA) was used. The temperature gradient was as follows: $80^{\circ} \mathrm{C}$ for $1 \mathrm{~min}$, rate of 8 ${ }^{\circ} \mathrm{C} / \mathrm{min}$ to $210^{\circ} \mathrm{C}$ for $2 \mathrm{~min}$. Helium (Linde Gas, Romania) has been used as carrier gas, at a mass flow of $1 \mathrm{~mL} / \mathrm{min}$, while the injector and ion source temperatures has been kept at 250 and $150^{\circ} \mathrm{C}$, respectively. The injection volume was $1 \mu \mathrm{L}$, with a split rate of 1:20. The compounds have been identified using NIST spectra library [28,29].

\section{Results and discussions}

The results showed that in the essential oil of Lavandula angustifolia Mill., Moldoveanca 4 var., obtained by hydro distillation, the number and quantity of organic compounds varies during the period taken in the study. Also, the concentration of all chemical components identified in the essential oils differs from one year to another (Table 2).

Table 2. The chemical composition of Lavandula angustifolia essential oil, Moldoveanca 4 variety, during 2016-2018

\begin{tabular}{|l|c|c|c|c|c|}
\hline \multirow{2}{*}{ No. } & \multirow{2}{*}{ Compound } & Retention time & $\mathbf{2 0 1 6}$ & $\mathbf{2 0 1 7}$ & $\mathbf{2 0 1 8}$ \\
\cline { 3 - 6 }$(\mathbf{m i n})$ & & \multicolumn{3}{|c|}{$\mathbf{\%}$} \\
\hline 1. & $\alpha-$-Thujene & 6.17 & 0.37 & 0.50 & 0.21 \\
\hline 2. & $\alpha$-Pinene & 6.40 & 0.78 & 0.84 & 0.47 \\
\hline 3. & Camphene & 7.09 & 0.50 & 0.38 & 0.25 \\
\hline 4. & $\beta$ - Pinene & 7.21 & 0.29 & 0.15 & 0.12 \\
\hline 5. & $\beta$ - Terpinene & 7.40 & 2.42 & 1.54 & 1.08 \\
\hline 6. & $\alpha$-Phellandrene & 7.42 & 0.05 & 0.23 & 0.14 \\
\hline 7. & Delta-3-Carene & 7.45 & 1.23 & 0.53 & 0.59 \\
\hline 8. & o-Cymene & 7.50 & 0.03 & 0.08 & 0.04 \\
\hline 9. & p-Cymene & 7.52 & 0.58 & 0.39 & 0.22 \\
\hline 10. & Limonene & 7.72 & 2.44 & 0.62 & 0.38 \\
\hline 11. & $1,8-$-Cineole & 7.73 & 1.59 & 1.27 & 0.99 \\
\hline 12. & tran- $\beta$-Ocimene & 7.83 & 4.70 & 3.20 & 4.65 \\
\hline 13. & cis- $\beta$-Ocimene & 8.00 & 0.42 & 0.32 & 3.24 \\
\hline 14. & $\gamma$-Terpinene & 8.18 & 0.27 & 0.10 & 0.16 \\
\hline 15. & cis-Linalool oxide & 8.22 & 0.03 & 0.02 & 0.05 \\
\hline 16. & Terpinolene & 8.70 & 0.1 & 0.1 & 0.14 \\
\hline 17. & Linalool & 8.81 & 26.22 & 23.51 & 27.39 \\
\hline 18. & Allo-Ocimene & 9.25 & 4.60 & 2.77 & 5.94 \\
\hline 19. & Camphor & 9.52 & 0.23 & 0.22 & 0.17 \\
\hline 20. & Borneol & 10.00 & 2.69 & 2.15 & 1.99 \\
\hline 21. & Terpene-4-ol & 10.20 & 2.91 & 5.18 & 2.62 \\
\hline 22. & $\alpha$-Terpineol & 11.04 & 1.00 & 0.28 & 0.66 \\
\hline 23. & Linalyl acetate & 11.10 & 26.60 & 40.66 & 38.03 \\
\hline 24. & $\alpha-$ Terpenyl acetate & 11.58 & 2.27 & 1.69 & 2.00 \\
\hline 25. & Neryl acetate & 12.07 & 0.41 & 0.05 & 0.10 \\
\hline 26. & Geranyl acetate & 12.95 & 0.05 & 0.03 & 0.05 \\
\hline 27. & Caryophyllene & 13.40 & 4.35 & 4.20 & 4.53 \\
\hline & & & &
\end{tabular}




\begin{tabular}{|l|c|c|c|c|c|}
\hline 28. & Germacrene & 13.79 & 0.27 & 0.90 & 0.74 \\
\hline 29. & Cadinene & 14.18 & 0.25 & 0.23 & 0.32 \\
\hline 30. & Muurolene & 14.58 & 0.12 & 0.09 & 0.13 \\
\hline
\end{tabular}

During the development of inflorescence and of flowers in inflorescences, the essential oil content varies, also changing the semi-quantitative composition of the oil, depending on the amount of glandular trichomes and their content $[1,2,30]$. The researches confirmed the variation in the number of components from 17 to 38, identified in the essential oil separated through hydro distillation under laboratory conditions from the fresh inflorescences obtained from the species Lavandula angustifolia L. [31, 32]. The plant product used at this stage was harvested in the most favourable phase of the plant evolution for the extraction of essential oil.

Relatively low temperatures facilitate the formation of linalool. Depending on the content of linalyl acetate, the superior or inferior quality of the oil is determined. The content of more than $1.2 \%$ of camphor significantly reduces the aroma and the quality of the oil [1,6]. Alpha-terpineol has a pronounced lilac flavour, while the terpineol type substances are known for their antimicrobial and antifungal properties. It is believed that terpinen-4-ol in high concentrations $(>2 \%)$ diminishes the essential oil value, giving it a flavour of grass [30]. In the tested product, camphor ranged within very small limits, reaching a maximum concentration of $0.23 \%$ in 2016, and the concentration of terpene-4ol ranged from 2.62 to $5.18 \%$ in 2018 (Table 2).

The main component of lavender essential oil is linalool (40-60\%), both free and partially esterified, in the form of linalyl acetate [5]. It is believed that high quality essential oil contains 46-48 $\%$ of linalyl acetate $[1,6]$. In all the samples, 30 organic compounds were identified, linalool and linalyl acetate being in approximately equal concentrations, varying from 23.51-27.39\% linalool and from 26.60-40.66 \% linalyl acetate (Table 2). To determine the chemical composition of Lavandula angustifolia essential oil in the all three years of study (2016-2018), the essential oil was analysed semi-quantitatively using gas chromatography coupled with mass spectrometry (GC-MS) (Figures 24).

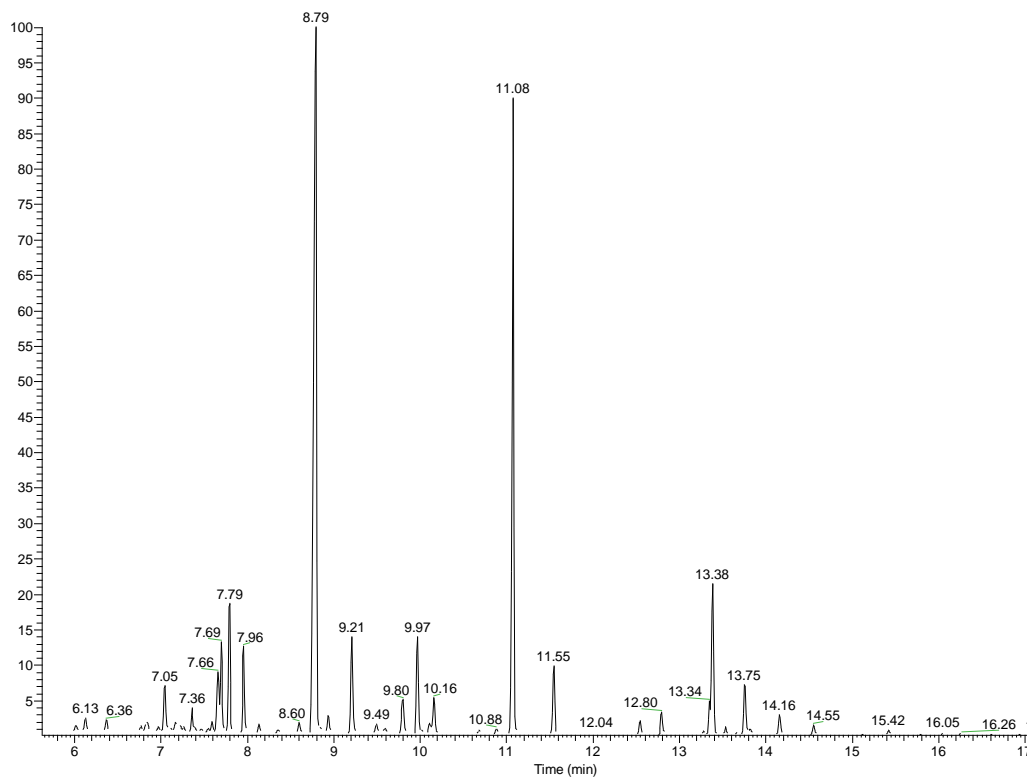

Figure 2. GC-MS

chromatogram of Lavandula

angustifolia essential oil, obtained in 2016

In the year 2017, changes in chemical composition were observed (Figure 3). Compared to the previous year, there was an increase in the quantity of linalyl acetate from 26.60 to $40.66 \%$, and a slight decrease in the content of linalool (26.22 vs. $23.51 \%)$. The analysis performed for the lavender essential oil obtained in 2018 reveals differences in the amounts of chemical components, both compared to 2016 and 2017 (Figure 4). The concentration of linalyl acetate remains approximately the 
same as in 2017 (38.03 versus $40.66 \%$ ) and there is an increase in the quantity of linalool compared to previous years (27.39\% compared to $23.51 \%$ in 2017 and $26.22 \%$ in 2016)

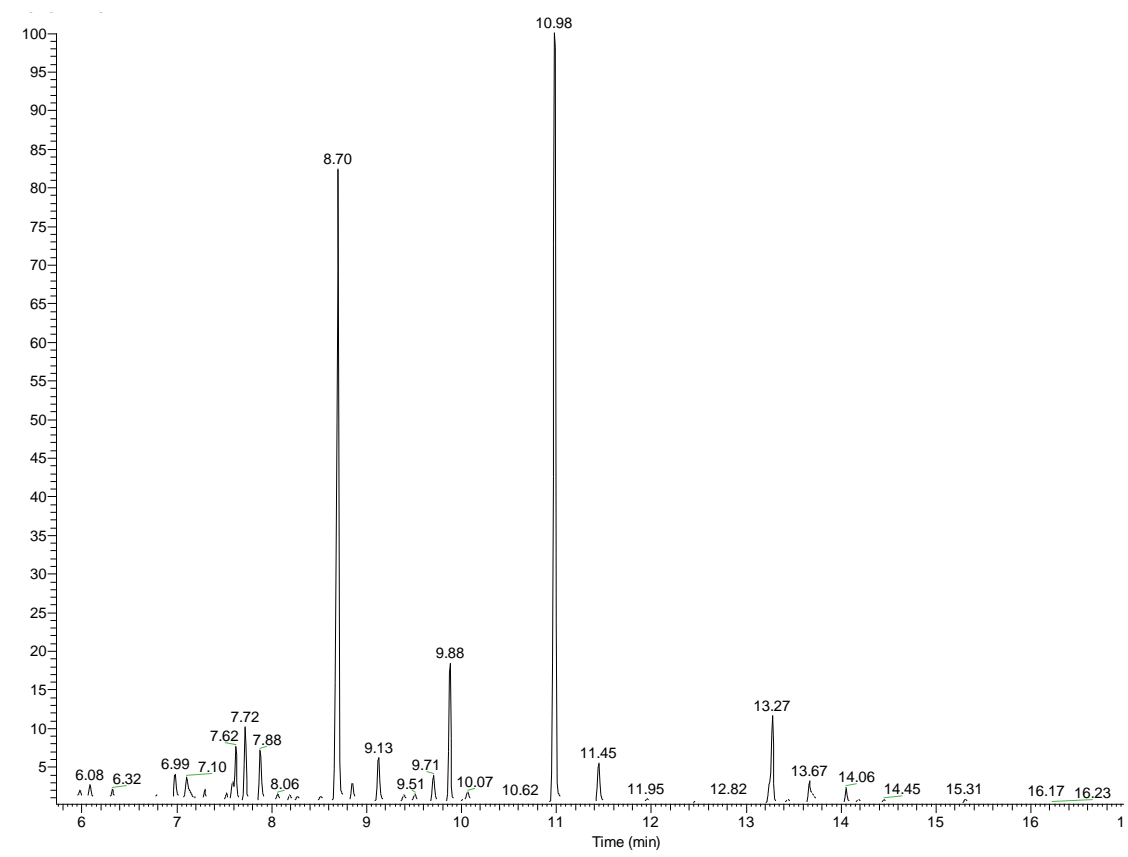

Figure 3. GC-MS chromatogram of Lavandula angustifolia essential oil, obtained in 2017

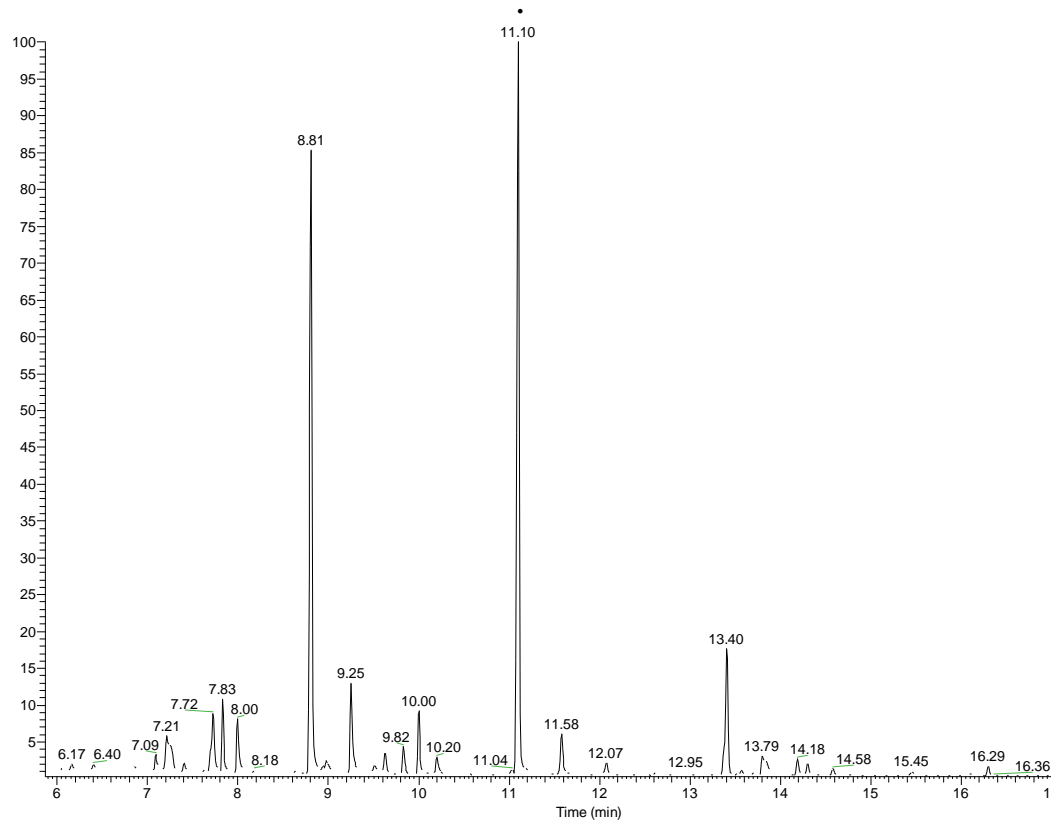

Figure 4. GC-MS chromatogram of Lavandula angustifolia essential oil, obtained in 2018

It has to be noted that the chemical composition of the lavender essential oils obtained in 20162018 was maintained in the standards range [33]. The minimal concentration of the camphor (less than $0.23 \%$ in our samples) lead to the enhanced aroma of the oil. The modest concentration of terpinen-4ol (less than 8\%, as recommended in the standard [33]) confers a good quality of the studied lavender essential oils. Also, the concentration of trans- $\beta$-ocimene $(3.20 \%$ in $2017,4.65 \%$ in $2018,4.70 \%$ in 
2016) and cis- $\beta$-ocimene $(0.32 \%$ in $2017,0.42 \%$ in $2016,3.24 \%$ in 2018$)$ are in the accepted range of the standard $(0.5-6 \%$ trans- $\beta$-ocimene and max. $10 \%$ cis- $\beta$-ocimene).

Regarding this Romanian variety, our results demonstrated that the principal components are almost identical to those identified in other species of lavender from Poland [30], China [31], India [32], etc. The information provided by some articles specified several compounds found in lavender essential oils (which was obtained by using the same method of hydro distillation) [35,36]. Da Porto et al. describes 60 compounds, and Danh et al. obtained 45 compounds, which represents a significant higher number of active substances versus only 30 components identified in the present work [35,36].

These qualitative inconsistencies in the chemical composition of the essential oils obtained from plants, as it was already mentioned, reported in various specialized studies, are due to multiple causes, beginning with the growing / cultivation conditions, as well as with the mode and period of harvesting, and finishing with different operating conditions during the extraction process [19-23]. As it is well known, each type of lavender oil is described by a specific, distinctive profile from the qualitative / quantitative point of view, presenting different chemical compounds, in different quantity and in different number; therefore, depending on their composition, each of these oils have different chemical, physical, and therapeutic properties (e.g. the concentration of linalyl acetate determines the quality of lavender essential oil used in perfumery, larger quantities being associated with a higher quality of the perfume; on the other hand, the concentration of linalool influences the antimicrobial properties of the essential oil) $[1,5,35,36]$.

\section{Conclusions}

Determination of the variations in the chemical composition of the essential oil of Lavandula angustifolia Mill., Moldoveanca 4 variety, showed important changes in chemical composition, by using GC-MS technique, a semi-quantitative method. The plans under analysis were obtained in different years, under the same conditions of cultivation, harvesting and extraction methods. The results exhibited the good products quality as it contains high quantity of linalyl acetate (40.66\%, maximum in 2017), linalool (between $23.51 \%$ in 2017 and $27.39 \%$ in 2018) and small amount of camphor $(0.23 \%$, maximum in 2016). The variation of the chemical profile of lavender essential oil obtained during the three years of research demonstrates, once again, that it is necessary to analyse each sample of essential oil when it is about of using it in therapy, because the components may be determinant in the pharmacological/therapeutic properties.

\section{References}

1.MASCOVTEVA, S., Influence of the maternal form on the creation of performance hybrids Lavandula angustifolia Mill., Instit. of Genetics, Physiology and Plant Protection of the ASM, PhD Thesis, Chisinau, Moldova, 2018, pp. 30-56.

2PIRVU, C., PIRVU, A.S., Enciclopedia Plantelor Medicinale din flora Romaniei (Encyclopedia of Medicinal Plants of Romania Flora), vol. 1, ASAB, Bucharest, 2016, pp. 466-469.

3.ROBU, S., CHESARU, B.I., DIACONU, C., DUMITRIU-BUZIA, O., TUTUNARU, D., STANESCU, U., LISA, E.L., Lavandula hybrida: microscopic characterization and the evaluation of the essential oil, Farmacia, 64(2), 2016, 914-917

4.BOGDAN, M., ENDRES, L., PASCA, B., TIT, D.M., UIVAROSAN, D., COPOLOVICI, D.M., ALEYA, L., BUNGAU, S., Study on the Stability and Compatibility of the Cosmetic Products with Lavandula angustifolia Oil Kept in PPH Polypropylene Homopolymer Plastic Containers, Mater. Plast., 56 (2), 2019, 133-137. https://doi.org/10.37358/MP.19.1.5138

5.ELSHARIF, S.A., BANERJEE, A., BUETTNER, A., Structure-odor relationships of linalool, linalyl acetate and their corresponding oxygenated derivatives, Front. Chem., 3, 2015, 1-10. https://doi.org/ 10.3389/fchem.2015.00057

6.BABAR, A., AL-WABEL, N.A., SHAMS, S., AHAMAD, A., SHAH A.K., ANWAR, F., Essential oils used in aromatherapy: A systemic review, Asian Pacific J. Trop. Biomed., 5(8), 2015, 601-611.

https://doi.org/10.1016/j.apjtb.2015.05.007 
7.***Romanian Farmacopeea, $\mathrm{X}^{\text {th }}$ ed., Ed. Medicala, Bucharest, 2010, 583.

8.***European Pharmacopoeia, $9^{\text {th }}$ ed. (Ph. Eur.) including Supplement, 2017.

9.LOPEZ, V., NIELSEN, B., SOLAS, M., RAMIREZ, M.J., JAGER, A.K., Exploring Pharmacological Mechanisms of Lavender (Lavandula angustifolia) Essential Oil on Central Nervous System Targets, Frontiers Pharmacol., 8, 2017, 1-8. https://doi.org/10.3389/fphar.2017.00280

10.DEDIU, G., DIACONU, C., DUMITRACHE RUJINSKI, S., IANCU, A., BALACEANU, A., DINA, I., BOGDAN, M., May inflammatory markers be used for monitoring the continuous positive airway pressure effect in patients with obstructive sleep apnea and arrhythmias? Medical Hypotheses. 115, 2018, 81-86.

11.GHEORGHE, G., PANTEA STOIAN, A., GAMAN, M.A., SOCEA, B., NEAGU, T.P., STANESCU, A.M.A., BRATU, O.G., MISCHIANU, D.L.D., SUCEVEANU, A.I., DIACONU, C.C., The benefits and risks of antioxidant treatment in liver diseases, Rev. Chim., 70(2), 2019, 651-655.

12.DIACONU, C., Midaortic syndrome in a young man, Cor et Vasa. 59, 2017, e171-e173. doi: 10.106/j. crvasa.2016.04.007

13.BALDINGER, P., HOFLICH, A.S., MITTERHAUSER, M., HAHN, A., RAMI-MARK, C., SPIES, M., WADSAK, W., LANZENBERGER, R., KASPER, S., Effects of silexan on the serotonin-1a receptor and microstructure of the human brain: a randomized, placebo-controlled, double-blind, cross-over study with molecular and structural neuroimaging, Int. J. Neuropsychopharmacol., 18(4), 2015, 1-9.

doi: $10.1093 /$ ijnp/pyu063

14.NIKFARJAM, M., PARVIN, N., ASSARZADEGAN, N., ASGHARI, S., The Effects of Lavandula Angustifolia Mill Infusion on Depression in Patients Using Citalopram: A comparison Study, Iran. Red. Crescent Medical J., 15(8), 2013, 734-739. doi: 10.5812/ircmj.4173

15.SENNA, M.D., LES, F., LOPEZ, V., GALEOTTI, N., Lavender (Lavandula angustifolia Mill.) Essential oil alleviates neuropathic pain in mice with spared nerve injury, Frontiers Pharmacol., 10, 2019, 472. doi: 10.3389/fphar.2019.00472

16.VAN DER PLOEG, E., EPPINGSTALL, B., O'CONNOR, D., The study protocol of a blinded randomised-controlled cross-over trial of lavender oil as a treatment of behavioural symptoms in dementia, BMC Geriatrics, 10(1), 2010, 49, 1-5. doi: 10.1186/1471-2318-10-49

17.SNOW, L., HOVANEC, L., BRANDT, J., A controlled trial of aromatherapy for agitation in nursing home patients with dementia. J. Altern. Complement. Med., 10(3), 2004, 431-437.

18.CHIOCA, L.R., FERRO, M.M., BARETTA, I.P., OLIVIEIRA, S.M., SILVA, C.R., FERREIRA, J., LOSSO, E.M., ANDREATINI, R., J. Anxiolytic-like effect of lavender essential oil inhalation in mice: participation of serotonergic but not GABAA/benzodiazepine neurotransmission, Ethnopharmacol, 147(2), 2013, 412-418. doi: 10.1016/j.jep.2013.03.028

19.GITEA, M.A., GITEA, D., TIT, D.M., PURZA, L., SAMUEL, A.D., BUNGAU, S., BADEA, G.E., ALEYA, L. Orchard management under the effects of climate change: implications for apple, plum, and almond growing. Environ. Sci. Pollut. Res., 26(1), 2019, 9908-9915

https://doi.org/10.1007/ s11356-019-04214-1

20.SAMUEL, A.D., BREJEA, R., DOMUTA, C., BUNGAU, S., CENUSA, N., TIT, D.M., Enzymatic indicators of soil quality, J. Environ. Prot. Ecol., 18(3), 2017, 871-878.

21.SAMUEL, A.D., TIT, D.M., MELINTE (FRUNZULICA), C.E., IOVAN, C., PURZA, L., GITEA, M., BUNGAU S., Enzymological and physicochemical evaluation of the effects of soil management practices, Rev. Chim., 68(10), 2017, 2243-2247.

22.MOISA, C., LUPITU, A., POP, G., CHAMBRE, D.R., COPOLOVICI, L., CIOCA, G., BUNGAU, S., COPOLOVICI, D.M., Variation of the chemical composition of Thymus vulgaris essential oils by phenological stages, Rev. Chim., 70(2), 2019, 633-637.

23.ABDEL-DAIM, M.M., EL-TAWIL, O.S., BUNGAU, S.G., ATANASOV, A.G., Applications of antioxidants in metabolic disorders and degenerative diseases: Mechanistic approach, Oxid. Med. Cell. Longev., 2019, 2019, 1-3. https://doi.org/10.1155/2019/4179676

24.MARIES, G.R.E., BUNGAU, C., CHIRA, D, COSTEA, T., MOSTEANU, D.E., Study on the influence of the grind percentage over the surface hardness and modulus of elasticity of parts made of acrylonitrile butadiene styrene, polyamide 6.6 and polyoxymethylene polymers, through nanoindentation, Mater. Plast., 56(1), 2019, 65-70. 
25.MARIES, G.R.E., CHIRA, D., BUNGAU, C., COSTEA, T., MOLDOVAN, L., Determining the influence of the processing temperature by injection and of the subsequent pressure on the surface's hardness and indentation modulus of the products made of HDPE, PMMA, PC+ABS through nanoindentation - G-Series basic hardness modulus at a depth method, Mater. Plast., 54(2), 2017, 214-220. 26.CHIRA, D., MARIES, G.R.E. BUNGAU, C. The influence of subsequent pressure of (HDPE), (PMMA), (PC+ABS) on some mechanical properties of items obtained through injection, Mater. Plast., 52(4), 2015, 572-577.

27.MARIES, G.R.E., CHIRA, D., BUNGAU, C, The influence of processing temperatures of (HDPE), (PMMA), (PC plus ABS) on some mechanical properties of items obtained through injection, Mater. Plast. 52(4), 2015, 452-456.

28.COPOLOVICI, D., BUNGAU, S., BOSCENCU, R, TIT, D. M., COPOLOVICI, L., The fatty acids composition and antioxidant activity of walnut cold press oil, Rev. Chim., 68(3), 2017, 507-509.

https://doi.org/10.37358/RC.17.3.5489

29.TOMESCU, A., SUMAlAN, R.M., POP, G., ALEXA, E., POIANA M.A., COPOlOVICI, D.M., STROE MIHAI, C.S., NEGREA, M., GALUSCAN, A., Chemical composition and protective antifungal activity of Mentha piperita L. and Salvia officinalis L. essential oils against Fusarium graminearum spp., Rev. Chim., 66(7), 2015, 1027-1030.

30.LYCZKO, J., JALOSZYNSKI, K., SURMA, M., MASZTALERZ, K., SZUMNI, A., HS-SPME Analysis of True Lavender (Lavandula angustifolia Mill.) Leaves Treated by Various Drying Methods, Molecules, 24(4), 2019, 764. doi: 10.3390/molecules24040764

31. SAADATIAN, M., AGHAEI, M., FARAHPOUR, M., BALOUCHI, Z., Chemical composition of lavender (Lavandula officinallis L.) extraction extracted by two solvent concentrations, Global $J$. Medicinal Plant Res., 1(2), 2013, 214-217.

32. VERMA, R.S., RAHMAN, L.U., CHANOTIYA, C.S., VERMA, R.K., CHAUHAN, A., YADAV, A., SINGH, A., Essential oil composition of Lavandula angustifolia Mill cultivated in the mid hills of Uttarakhand, India, J. Serb. Chem. Soc., 75(3), 2010, 343-348.

33.*** ISO 3515:2002, Oil of lavender (Lavandula angustifolia Mill.), https://www.iso.org/obp/ ui/\#iso:std:iso:3515:ed-3:v1:en, accessed (14.04.2020).

34.SHELliE, R., MONDELlO, L., MARRIOTT, P., DUGO, G., Characterization of lavender essential oils by using gas chromatography-mass spectrometry with correlation of linear retention indices and comparison with comprehensive two-dimensional gas chromatography, J. Chromatogr. A., 970(1-2), 2002, 225-234.

35.DA PORTO, C., DECORTI, D., KIKIC, I., Flavour compounds of Lavandula angustifolia L. to use in food manufacturing: comparison of three different extraction methods. Food Chem., 112, 2009, 1072-1078. 36.DANH, L.T., HAN, L.N., TRIET, N.D.A., ZHAO, J., MAMMUCARI, R., FOSTER N., Comparison of chemical composition, antioxidant and antimicrobial activity of lavender (Lavandula angustifolia L.) essential oils extracted by supercritical CO2, hexane and hydrodistillation, Food Bioprocess Technol., 6(12), 2012. Doi: 10.1007/s11947-012-1026-z

$\overline{\text { Manuscript received: } 4.07 .2019}$ 